\title{
AZ EGYETEMI KÖZPONTÚ VÁLLALKOZÓI ÖKOSZISZTÉMA ÉS A KÖZÖSSÉGI FINANSZÍROZÁS KAPCSOLATA
}

Az egyetemi vállalkozói ökoszisztéma kérdésköre a felsőoktatási intézmények harmadik missziójának irányába illik, ahol is megjelenik a helyi gazdasági-társadalmi környezetből eredő problémák megoldásában vállalt aktív tevékenység. A szerzők tanulmányukban először definiálják az egyetemi vállalkozói ökoszisztéma fogalmát, majd rámutatnak az egyetemi közösségi finanszírozás (crowdfunding) rendszerszemléletű integrálásának kihívásaira ebben a kontextusban. A vállalkozói ökoszisztémába integrált közösségi finanszírozás révén az egyetemek forrásközvetítői szerepet is vállalhatnak a kibertérben. A régióban és az intézményi kereteken belül létrejött üzleti ötletek és azok korai fázisú finanszírozása közé a „platformosodás" jegyében infrastruktúrákat, üzleti hálózatokat szervezhetnek és kultúrát építhetnek a felsőoktatási intézmények, melyek révén elősegítik az információs technológiákon át áramoltatott erőforrások hatékonyabb allokációját, az innovatív projektötletek felismerését, fejlesztését és alternatív finanszírozását. A projektötletek keresleti oldala és helyi közösségekben rejlő finanszírozási kínálat közötti piactér megteremtése mellett innovatív oktatási módszerekkel is támogatni kell az egyetemi közösségi finanszírozás sikerét. Empirikus kutatásukban rámutatnak arra, hogy a hallgatói vállalkozásfejlesztési programok gazdag interakciós oktatási környezete emeli a crowdfundinggal kapcsolatos hallgatói nyitottságot mind részvételi szándék, mind támogatási hajlandóság oldalon.

\section{Kulcsszavak: egyetemi vállalkozói ökoszisztéma, közösségi finanszírozás}

A tanulmányunk a hazai szakirodalomban is jelenlevő vállalkozói ökoszisztéma (Szerb, 2017), a vállalkozói, vállalkozásfejlesztési képzés módszertana (Imreh-Tóth, 2015; Gál et al., 2017; Árváné et al., 2017), az innováció és a közremüködő szervezetek közötti együttmüködés (Dőry - Gajzágó, 2015) témák által körvonalazott kutatási sodorvonalba illeszkedik, hozzáadott értéket az egyetemi vállalkozói ökoszisztéma fogalmának definiálásával és az egyetemi közösségi finanszírozás ökoszisztémába való beágyazásának kérdéseivel teremt.

Az egyetemek szerepe, velük szemben támasztott elvárások a regionális társadalmi-gazdasági térben megváltozni, átformálódni látszanak (Goldstein, 2009; Luger - Goldstein, 1997). A tudásgeneráláson, oktatáson és kutatásfejlesztésen túl társadalmi elvárás, hogy az intézmény keretei között folyó tevékenységekből új kezdeményezések, termékek, szolgáltatások szülessenek, melyek képesek a helyi, régiós társadalmi-gazdasági problémákra megoldást adni (Etzkowitz, 1998; Etzkowitz - Leydesdorff, 2000; Göktepe-Hulten - Mahagaonkar, 2010). Nem csupán a globális problémákat megoldó nagy költségvetésü, hosszú lefutású kutatási projektek jelentenek értéket, hanem az olyan, akár egyetemi hallgatók által kezdeményezett projektek is, amik egy régiós érdekelti csoportok számára nyújtanak segítséget abban, hogy a számukra nehézséget jelentő tényezőket leküzdjék.

Ahhoz, hogy az egyetemek - itthon és külföldön egyaránt - meg tudjanak felelni eme követelménynek, át kell alakítaniuk az évtizedek során megszokott tevékenységeiket, szervezeti struktúrájukat, valamint, s talán ez a legnagyobb kihívás, a közgondolkodást (Clark, 1998). Az egyetemi polgárok - kutatók, oktatók, hallgatók, admi- nisztratív munkatársak - körében a mindennapi gondolkodás részévé kell, hogy váljon a vállalkozói orientáció, ugyanis a problémák megoldását jelentő kezdeményezések, termékek és szolgáltatások, esetenként innovációk megszületéséhez elengedhetetlen a vállalkozói szemléletmód.

Termékeny vállalkozóknak (productive entrepreneur) nevezzük azokat, akik a vállalkozói szemléletmód eredőjeként képesek megfogalmazni olyan kezdeményezéseket, melyek még nem létező megoldásokat nyújtanak még orvosolatlan problémákra, vagy már meglévő megoldásokat fejlesztenek tovább (Baumol, 1993). A termékeny vállalkozók tevékenysége nyomán jön létre az a vállalkozói aktivitás, ami új szervezetekben, kooperációkban formalizálódik, s hoz létre értéket, formál szemléletet, generál új lehetőségeket a régiós érintettek számára. Az a termékeny vállalkozó, aki nem csupán a saját foglalkoztatására, megelégedettségére törekszik a tevékenysége során, hanem kiemelt célnak tekinti a magas teljesítményt, hozzáadott értéket, változást generáló potenciált, gyors skálázhatóságot (Stam et al., 2012). Ez a vállalkozó a leghatékonyabban és leggyorsabban egy inspiratív, motiváló, erőforrás integrációt támogató közegben, más néven vállalkozói ökoszisztémában képes fejlődni, ahol egymástól függő, s egymásra ható egyének és tényezők koordinált interakciója folyik, s ahol fontos a közös tanulás, tapasztalás, valamint a vállalkozói kezdeményezés fejlesztése, továbbá folyamatos a visszacsatolás és értékelés (Stam, 2015).

Amennyiben az egyetem valóban meg kíván felelni annak a társadalmi-gazdasági elvárásnak, miszerint vállaljon aktív szerepet új termékek, szolgáltatások s kezdeményezések felkarolásában, feltétlenül szükséges egy 
egyetemközpontú vállalkozói ökoszisztéma (EVÖ) létrehozása, fenntartása és fejlesztése. Az EVÖ-nek hatást kell gyakorolnia az egyetem alaptevékenységeire - oktatás, kutatás, technológiatranszfer -, valamint valóssá, értékteremtővé kell tennie a régiós társadalmi-gazdasági szereplökkel folytatott interakciót (outreach).

Tanulmányunkban bemutatjuk az egyetemközpontú vállalkozói ökoszisztéma koncepcióját, amit a Stam-féle vállalkozói ökoszisztéma-rendszerre alapozva alkottunk meg. Az egyetemközpontú vállalkozói ökoszisztéma-modellben számba vesszük a rendszerelemeket, a közöttük fennálló összefüggéseket, valamint az ökoszisztéma müködése következtében előálló kimeneteket, eredményeket. A közösségi finanszírozás példáján keresztül rávilágítunk több rendszerelem, a finanszírozás, az oktatási programok és a kultúrateremtés jelentőségére, valamint empirikusan vizsgáljuk a közösségi finanszírozás oktatásának vállalkozói aktivitásra gyakorolt hatását.

\section{A vállalkozói ökoszisztéma}

A vállalkozói ökoszisztémát mint a régiós vállalkozói aktivitást befolyásoló tényezőt középpontba állító tudományos vizsgálatok a kétezres évek elején kezdtek megjelenni internetes technológiákkal foglalkozó vállalatok (Zacharakis et al., 2003), startup vállalkozások (Napier Hansen, 2011), innovációs hálózatok (Malecki, 2011; Feld, 2012), valamint gazdasági és regionális fejlesztés (Isenberg, 2011; Kantis - Federico, 2011) témakörökben. Az irodalom azon túl, hogy vizsgálta az ökoszisztéma vállalkozói aktivitásra gyakorolt hatását (Ucbasaran et al., 2001; Welter, 2011; Zahra et al., 2014; Autio et al., 2014), felismerte a vállalkozó egyén városi és regionális gazdasági növekedésben betöltött szerepét (Acs - Armington, 2004; Feldman, 2001; Glaeser et al., 2010), valamint különbséget tett „átlagos” és „termékeny” (productive entrepreneur) vállalkozó között (Henrekson - Sanandaji, 2014; Stam et al., 2009; 2011; Wong et al., 2005). Az irodalomban fellelhető megállapítások szintézisére alapozott első definíciót Brown és Mason (2014, p. 775.) fogalmazta meg az alábbiak szerint:

„A vállalkozói ökoszisztéma olyan egymással öszszeköttetésben, interakcióban álló vállalkozó szemléletü egyének, szervezetek (pl.: vállalatok, kockázatitöke-alapok, bankok), intézmények (egyetemek, állami ügynökségek) koncentrációja, melyben vállalkozásspecifikus folyamatok vannak jelen (új, magas növekedési potenciájú vállalkozások születésének magas foka, magas likvidációs ráta, sorozatvállalkozók, sikeres vállalkozók magas elöfordulása), s melyet formális és informális folyamatok müködtetnek, kormányoznak." A definícióalkotáson túl Stam (2015) javaslatot tett egy koncepcionális keretrendszerre (1. ábra), ami az egyének és a tényezők közötti kölcsönhatást, $\mathrm{s}$ a rendszert felépítő elemeket, valamint a rendszer kimeneteit is meghatározta. Stam meghatározása szerint a vállalkozói ökoszisztéma olyan függőségi viszonyban lévő aktorok és tényezők összessége, melyek koordinációja nyomán termékeny vállalkozói aktivitás jön létre egy adott területi egységen belül.
Stamet (2015) megelőzően az irodalomban felmerülő koncepcionális keretrendszerek (lásd Isenberg, 2011) túl komplexek és szerteágazóak voltak, ezáltal nem tudták operacionalizálni az egymásra ható tényezőket, következésképpen empirikus vizsgálatokban történő alkalmazhatóságuk erősen korlátos volt. Míg Isenberg (2011) ökoszisztémára vonatkozó koncepcionális modellje kevéssé volt fókuszált, addig az ökoszisztémába ágyazott vállalkozóegyén fejlődési pályájára vonatkozóan egy konkrét folyamatot definiált (2. ábra). Ez a pálya abban újszerü, hogy az ökoszisztéma-hatásból adódóan visszacsatolások figyelhetök meg benne. Ilyen visszacsatolás a tapasztalat megosztása, ami a lineáris fejlődési folyamat végét elért egyéntől származik, és segíti azokat a még korábbi fázisban lévő vállalkozókat, akiknek meg kell küzdeniük a startup vállalkozások kezdeti nehézségeivel. A második visszacsatolási lehetőség a tőkejuttatás a korai fázisban lévő vállalkozói kezdeményezések számára, ugyancsak azoktól az egyénektől, akik már sikerre vitték projektjüket, s rendelkeznek befektetni szánt vagyonnal. Ez a sikeres és tapasztalt vállalkozói kör nyújthat nagyon fontos támaszt az éppen vállalkozói szemléletét kialakító fiatal vállalkozók számára.

\section{A vállalkozói fejlődési folyamat az ökoszisztémában}

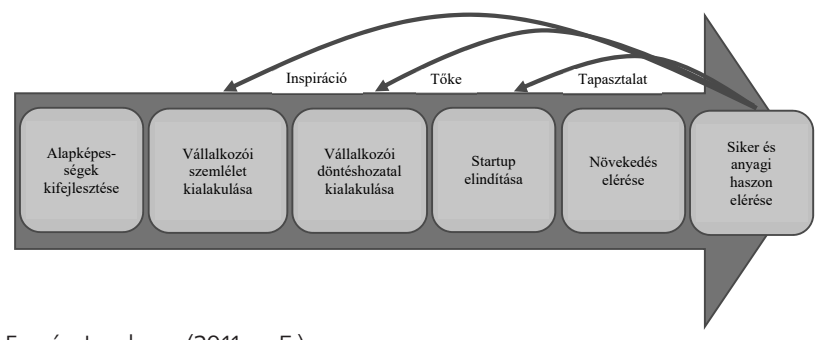

Forrás: Isenberg (2011, p. 5.)

Míg Isenberg (2011) nem azonosítja azokat a rendszerelemeket, amik interakciója nyomán kialakul az ökoszisztéma-hatás, felismeri az egyének közötti interakcióból származó „spillover” effektust, ami a fejlődési folyamatot körülvevő kontextusból következik. Stam (2015) ugyancsak számol a visszacsatolásból fakaró jótékony tanulási hatással (lásd a 2. ábra eredmény és kimenet dobozokból induló, s ökoszisztémába mutató nyilak), de ő már meghatározza azon rendszerelemeket, melyekben változás következik be a visszacsatolás eredményeképpen.

Stam a peremfeltételek közé sorolja azokat a tényezöket, amik az adott régióban adottságként azonosíthatók, s melyekből kifejlődnek az ökoszisztéma rendszerfeltételeit képező elemek. A formális intézmények a régiós szabályrendszereket, intézményi hálózatot jelentik, melyek kapcsolatban vannak a vállalkozó szellemü egyénekkel, $\mathrm{s}$ megteremtik azt a keretrendszert, amiben a vállalkozó mozoghat a fejlödése során. A kultúra az a nehezen megfogható környezeti tényező, ami a mindennapokban például a közbeszédben, az emberek gondolkodásában, nyitottságában, pozitivizmusában, lehetőségkereső attitüdjében, kockázathoz való viszonyulásukban érhető tet- 
ten. A fizikai infrastruktúra a vállalkozók közös tanulását, alkotását, interakcióját, valamint munkáját támogató létesítményhalmaz, amiket inkubátorházakként, közösségi munkaterekként, akcelerátorokként, fab lab-ekként szoktunk azonosítani. Ezt a tényezőt a regionális kutatások irodalma akként vizsgálja, hogy a település mint földrajzi egység, hogyan befolyásolja a termékeny vállalkozóiság, kreativitás, innováció terjedését. Florida és szerzőtársai (2016) álláspontja, hogy a település, esetükben a város, nagyobb mértékben járul hozzá a vállalkozói aktivitás fokozódásához, mint a nagyvállalatok katalizátor hatása, aminek legföbb oka, hogy a mai tudásalapú társadalomban a vállalkozóegyén számára, aki az innováció forrása is egyben, a legfontosabb kérdés a fizikai közelség, adottságok, interakciós lehetőségek.

A vállalkozói kezdeményezések fejlesztési folyamata során, valamint annak mérföldköveinél fontos szerep hárul a ,keresleti” oldal szereplöire, azaz olyan vállalatokra, amik ugyanazon vagy közeli piacon müködnek. Ezek a vállalatok egyrészt a termékek vagy szolgáltatások folyamatos validációjában, piaci tesztelésében segíthetnek, másrészt mint potenciális stratégiai partner involválódhatnak a fejlesztésbe. Azoknál a projekteknél, melyeknél a vállalkozó valamely oknál fogva nem indítja el a vállalkozást egy független jogi entitás formájában, a stratégiai partnerek vevőként is felléphetnek, s a projektet internalizálva saját termék- vagy szolgáltatásportfóliójuk részéve tehetik.

A vállalkozói ökoszisztéma elemei, kimenetei és eredményei

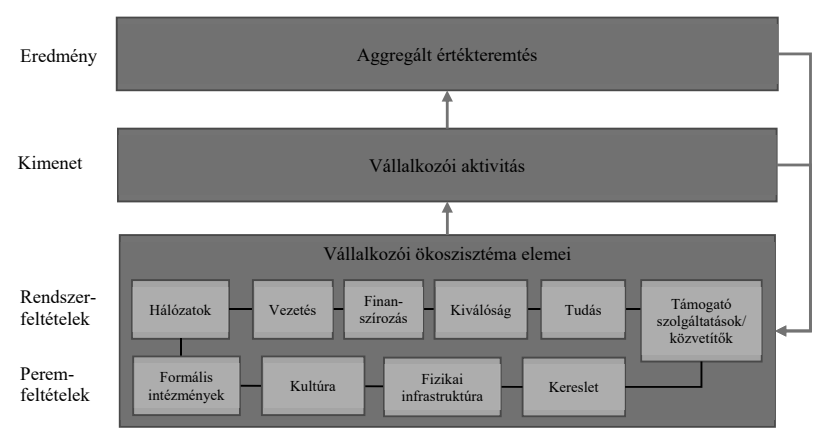

Forrás: Stam (2015, p. 6.)

A paraméter-feltételek nyomán változó rendszerfeltételek egyik részét alkotják a hálózatok, amelyek informálisan, az adott földrajzi egységben, alulról felfelé történő építkezés keretében alakulnak ki, és járulnak hozzá a vállalkozói aktivitáshoz. A hálózatok azok, amik a közös alkotás, tanulás, együttmüködés forrásául szolgálnak, s melyek számára értékes hozzájárulás lehet egy fizikai létesítmény, ami otthont ad a közös tevékenységnek. Az ökoszisztéma vezetési eleme nem összekeverendő egy hierarchikus szervezet vezetésével. Ebben a kooperációs térben vezető alatt azt a sikeres vállalkozót értjük, aki követendő példaképként azonosítható, s aki személyes és szakmai hírnevével inspirálja az ökoszisztéma többi tagját, s egy lehetséges utat mutat számukra. A vállalkozói kezdeményezések fejlesztéséhez elengedhetetlen a pénzügyi forrás rendelkezésre állása, értékelési szempontrendszerének köztudatban való jelenléte, ismerete a finanszírozási elem részét képezi. Ez az elem a finanszírozást nyújtó szereplők - angyali befektetők, kockázatitőke-társaságok, bankok, pályázati forrást nyújtó ügynökségek - mellett magában foglalja azt a tudásszintet is, ami lehetővé teszi az ökoszisztéma tagjai számára, hogy alternatív forrásszerzéssel éljenek közösségi finanszírozás, bootstrapping, családi, baráti, „örültek” (friends, family and fools - FFF) által juttatott források formájában. A ,kiválóság” és a „tudás” rendszerelemek az innováció forrását jelentik az ökoszisztémában. A tudás az egyéni és a kollektív tudásszintet testesíti meg, amit például egy adott régióban müködő egyetem generál, de hozzájárulhat a régióban működő vállalatok kutatás és fejlesztési tevékenysége is. A kiválóság halmazba azok az egyének tartoznak, akik a tudásbázis részeként törekvésükkel, tudásukkal elért eredményeikkel az innováció forrásául szolgálhatnak. Az új, korszerü tudással rendelkező egyének fejlődését a „támogató szolgáltatások/közvetitök" rendszerelembe tartozó szervezetek, folyamatok támogatják, mint például az akcelerátorok, inkubátorok, oktatási intézmények programjai, közvetítői szolgáltatást nyújtó állami, önkormányzati ügynökségek.

Az ökoszisztéma kimenete az ún. vállalkozói aktivitás, ami az ökoszisztéma müködésének közvetlen értékmérője, melyet az új vállalkozások, cégek számával, a bevont tőke mértékével, az új munkahelyek arányával, a bejegyzett iparjogvédelmi oltalmak, innovatív termékek, szolgáltatások számával lehet mérni. A vállalkozói aktivitás fokozódásának eredménye olyan össztársadalmi szinten megfigyelhető mutatók, indikátorok, folyamatok összessége, amik egy része mérhető, míg másik része inkább a mindennapokban észlelhető, mint például a nyitott, pozitív gondolkodás, befogadó, proaktív magatartás, bizalmi tőke foka, elbukástól való félelem csökkenése, bukás tolerálása. Mind a kimeneti szinten lévő vállalkozói aktivitás, mind pedig az eredménydimenzióban megkeletkező aggregált érték visszahat az ökoszisztéma elemeire.

\section{Az egyetemközpontú vállalkozói ökoszisztéma}

A következőkben a 2. ábrán látható koncepcionális rendszer elemeit az egyetemi kontextusba helyezzük, s a modell koncepcionális továbbfejlesztésére teszünk kísérletet. Azonosítjuk az egyetem keretei között müködö folyamatokat, meglévő viszonyokat, dolgozó szereplöket, akik az egyetemközpontú vállalkozói ökoszisztémát alkotják (lásd 1. táblázat). Ez a rendszer nem csupán a vállalkozói tevékenység potenciálját, hanem az intézmény régiós társadalmi-gazdasági beágyazódását, „,kinyúlását” (outreach) is meghatározza.

A formális intézmények alatt az egyetemi szférát szabályozó törvényeket, szabályokat értjük, amiket az intézmények saját szintjükön a szervezeti és működési szabályok révén operacionalizálnak. Ezek a szabályok definiálják például azt az intézményi stratégiát, ami a vál- 
lalkozóiság fejlesztését egyetemi szintre emeli, diszciplínákon átívelővé teszi, beépíti a tantervbe, a karokat és más vertikális szervezeti egységeket horizontális dimenzióban összekötő szervezeti egységeket hoz létre. A kultúra, hasonlóan egy adott régió vállalkozói kultúrájához, az egyetemi polgárok vállalkozói szellemiségét, gondolkodását, értékrendjét jelenti, ami az egyetem keretei között végzett tevékenység és létrejövő tudás hasznosulására hat. A fizikai infrastruktúra rendszerelembe azok az egyetemi létesítmények tartoznak, amik a transz-diszciplináris gondolkodást stimulálják, s amik támogatják az egyetemi polgárok és a külső érintettek találkozását, értékteremtését és tudásátadását. A vállalati kapcsolatok, ahogy a Stam-féle rendszerben is a külső impulzusokat biztosítják, visszacsatolást adnak az egyetemen folyó munka relevanciájához (validáció), hasznosítási partnerként jelennek meg, vagy éppen stratégiai vevőként megvásárolják a hallgatói vagy kutató/oktatói vállalkozói projektet. Ahhoz, hogy ez a keresletoldali ,szívó hatás” hatékonyan múködjön, az intézménynek szisztematikusan kell koordinálnia a vállalatokkal fenntartott kapcsolatot, hogy a megfelelő vállalat az értékteremtési folyamat megfelelő fázisában lépjen kontaktusba az ökoszisztéma tagjával, azaz az egyetemi polgárral. Az önszerveződés eredményeképpen kialakuló hallgatói szervezetek azon túl, hogy a közös tanulás inspiratív közegét alakítják ki, fejlesztik a hallgatók önmegvalósító, szervező készségét és képességét, amik a vállalkozóiság kiemelten fontos elemei.

1. táblázat

\section{Az egyetemközpontú vállalkozói ökoszisztéma} rendszerelemei

\begin{tabular}{|l|l|}
\hline $\begin{array}{l}\text { Stam-féle } \\
\text { rendszerelem }\end{array}$ & $\begin{array}{l}\text { Egyetemközpontú vállalkozói } \\
\text { okoszisztéma rendszereleme }\end{array}$ \\
\hline $\begin{array}{l}\text { Formális } \\
\text { intézmények }\end{array}$ & $\begin{array}{l}\text { Felsőoktatást szabályozó törvények, } \\
\text { egyetem szervezeti és müködési szabályzata }\end{array}$ \\
\hline Kultúra & Kultúra \\
\hline $\begin{array}{l}\text { Fizikai } \\
\text { infrastruktúra }\end{array}$ & $\begin{array}{l}\text { Közös alkotóterek, Fab-lab-ek, } \\
\text { inkubátorházak }\end{array}$ \\
\hline Kereslet & Vállalati kapcsolatok \\
\hline Hálózatok & Hallgatói klubok, egyesületek, szervezetek \\
\hline Vezetés & Hallgatói, kutatói, oktatói példaképek \\
\hline Finanszírozás & $\begin{array}{l}\text { Angyali befektetök, kockázati tökések } \\
\text { szisztematikus jelenléte, közösségi } \\
\text { finanszírozás }\end{array}$ \\
\hline Kiválóság & Hallgatói és kutatói talentumok \\
\hline Tudás & Tudományos mühelyek \\
\hline $\begin{array}{l}\text { Támogató } \\
\text { szolgáltatások/ } \\
\text { közvetítők }\end{array}$ & $\begin{array}{l}\text { Kurzusok, képzési programok, pitch } \\
\text { versenyek, vállalkozásfejlesztési központok, } \\
\text { TTO-k, karrierirodák }\end{array}$ \\
\hline
\end{tabular}

Forrás: második oszlop saját szerkesztés

A sikeres vállalkozó szellemű hallgatók, kutatók kiemelése, követendö példaképpé teheti ezen egyéneket, ami elfogadottabbá teheti a vállalkozói magatartást intézmény szerte (vezetés rendszerelem). A finanszírozási dimenzióban nem csupán a forráshoz való hozzáférés lehetősége a fontos kérdés, hanem a pénzügyi gondolkodás fejlett- sége, valamint a szereplők egyetemi vállalkozásfejlesztési folyamatban való részvétele. A potenciális finanszírozó által támasztott követelményrendszer fejleszti a projektgazdák, kutatók, hallgatók gondolkodását, ezáltal csökkenti a későbbi tőkebevonási fázisban a finanszírozókkal szembeni kiszolgáltatottságukat. A közösségi finanszírozás mint alternatív forrásbevonási lehetőség ezen kívül segít a széles körü piaci validációban, behozhatja az első felhasználókat, publicitást teremthet a projektnek, s nem utolsó sorban közösséget generálhat a koncepció köré. A magas társadalmi-gazdasági hasznosulással járó kutatási projektek, termék- vagy szolgáltatáskezdemények forrásai a tudásgenerálást végző tudományos és szakmai mühelyek, s az ezeket létrehozó és müködtető, bennük tevékenységet folytató kutatók és hallgatók. A műhelyek és az azokat létrehozó egyének az ökoszisztéma tudásés kiválóságelemeit testesítik meg. Végül, de nem utolsó sorban az egyetem által folytatott oktatási tevékenység és tudástranszfer-szolgáltatás az, ami a fejlesztési folyamat egyik motorja, legfőképpen, ha ezek a folyamatok követik a korszerü, s egyre dinamikusabban fejlődő oktatás-módszertani változásokat. E változások között szerepel a vállalkozói szemléletfejlesztés diszciplínáktól független, tantervbe történő integrációja, az alkalmazott tanulási módszerek (experiential learning) használata, a külső partnerek tanterembe történő behozatala, a projektalapú tanulás. Az inspirációul szolgáló, tanterven kívül eső (extra-curricular) események egyetemi szintü, koordinált megszervezése is nagyban hozzájárul a különféle fejlettségi fázisban lévő kezdeményezések fejlődéséhez.

\section{Az egyetemi közösségi finanszírozás lehetőségei}

A közösségi finanszírozás (1) nagyszámú, földrajzi elhelyezkedésében szórt tömeg által juttatott (2) kis összegü pénzbeli juttatásokat foglal magában, melyek (3) alternatív finanszírozást nyújtanak különösen kezdő vállalkozások számára, különféle (4) üzleti modellek mentén. Utóbbiak a forrásért cserében fizikai jutalmakat, üzleti részesedést, hitelkamatot vagy elégedettséget ígérnek (5) társadalmi vagy for-profit célok megvalósulásáért (6) online platformon keresztül (Alegre - Moleskis, 2016). A szerzőpáros a felsorolt hat tényezőt azonosította a közösségi finanszírozással kapcsolatos nemzetközi szakirodalomban szereplő definíciók alapján.

A közösségi finanszírozás és az egyetemi tevékenységek összekapcsolása viszonylag új fejlődési irány. Az egyetemeken létrejövő innováció és vállalkozói ötletek üzleti hasznosításának gyakran akadályt jelent a felsőoktatási intézmény forráskorlátja. Kiutat jelenthet ebből a helyzetből, ha az egyetem a kibertérben közvetítőként jelenik meg az ötletgazdák, valamint a forrásbirtokosok, egyetemi polgárok, regionális gazdasági szereplök vagy befektetők között.

Az egyetemi bázisú közösségi finanszírozással kapcsolatban két trend körvonalazódik a nemzetközi szakirodalom és gyakorlat alapján: az egyik, amikor az egyetemi platformok a társadalmi célú forrásgyüjtést célozzák 
meg, olyan nem profitorientált - gyakran kutatási - projektek finanszírozását egészíti ki a platformokon felajánlott összegekkel, melyek elősegítik az ügy legitimációját a társadalmi-gazdasági térben; míg a másik - a témánk szempontjából relevánsabb - irány a vállalkozásfejlesztési céllal működtetett crowdfunding portál. Az üzleti célú, egyetemi bázisú közösségi finanszírozás a tudástranszfer-irodák szempontjából lehetővé teszi, hogy az egyetemi tömegek startup-okat finanszírozzanak, a kutatók számára megnyitja a platform adataihoz való hozzáférést, az egyetemi tömegek könnyebben vonhatók be egyetemi projektekbe, az egyetemi startupok pedig forrást szerezhetnek, növelhetik az ismertségüket, a piacukat és hálózatokhoz férhetnek hozzá (Wieck et al., 2013). Az egyetemi közösségi finanszírozásban rejlő potenciál megértéséhez hasznos kutatási eredmény, hogy a vállalaton belüli crowdfunding kísérletek magas részvételi arányokat, a szervezeti egységek közötti nagyobb kollaborációt, korábban nem ismert együttmüködő partnereket, illetve a csoportprojektek, szakmai közösségek iránt mutatott nagyobb érdeklődést és elköteleződést váltottak ki (Muller et al., 2013), továbbá fokozták az önkéntes együttmüködési hajlandóságot (Muller et al., 2014).

Az egyetemek számára a saját közösségi finanszírozási platform lehetővé teszi a hallgatói, oktatói és az ökoszisztémában lévő vállalkozói ötletek megvalósításához szükséges pénzgyüjtést, a hallgatói ösztöndíj finanszírozását, az egyetemi programok és projektek forrásdiverzifikációját. A közösségi finanszírozás révén elősegíthető az egyetemi polgárok involválása nonprofit és for-profit célok megvalósítása érdekében. A crowdfunding továbbá az alumnival való kommunikáció és kapcsolattartás új csatornáját nyitja meg. Az egyetemi vállalkozói kapacitásfejlesztés és a közösségi finanszírozás integrált rendszere az ökoszisztéma fontos része (3. ábra).

3. ábra

\section{A közösségi finanszírozás helye az egyetemi} vállalkozói ökoszisztémában

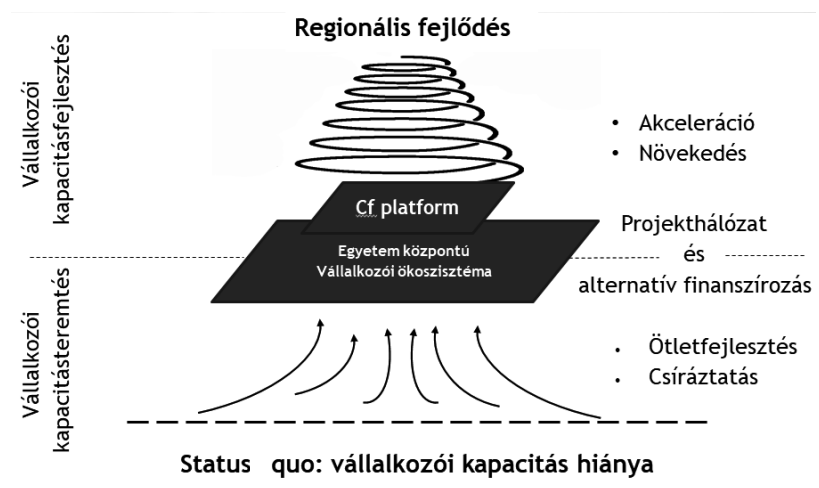

Forrás: Bedő $(2015$, p. 3.)

A vállalkozóisággal és vállalkozásfejlesztéssel kapcsolatos tudást, készségeket és képességeket a vállalkozói kapacitásteremtés fázisában sajátítják el az egyetemi hallgatók az egyetemi tanterv keretében. A tantervben különálló kurzusokként vagy kurzusokba beágyazott módon talál- koznak ezekkel az ismeretekkel az egyetemi hallgatók. Ezen ismeretek birtokában kezdődik meg az ötletek csíráztatásra, majd az ötletekből a piaci termékek és szolgáltatások fejlesztése. A 3. ábrán ez a folyamatrész az ábra alsó részében található. A hallgatók ekkor szerzik meg azokat az alapokat, amik lehetővé teszik számunkra, hogy a vállalkozói hálózatban, ökoszisztémában képesek legyenek másokkal kommunikálni, közösen dolgozni vagy közösen gondolkodni, mely folyamat kimenete a létrejött projekthálózat. A projektek érettségüktől függően alternatív finanszírozást szerezhetnek, ugyanis a projektfejlesztés a közösségi finanszírozási platform elvárásainak megfelelöen van kialakítva. A közösségi finanszírozási kampányok elindításával az egyetemmel kapcsolatban lévő szereplőktől és további külső támogatóktól forrásokat szerezhetnek. A külső szereplők projektekben történő részvétele az egyetem harmadik missziójának gyakorlati megvalósulása, aminek eredményeként regionális fejlődés jöhet létre, akkor, ha a projekt az akcelerációs növekedési szakaszban szervesül a régiós társadalmi-gazdasági környezetbe. Ezt az összefüggést a 3. ábra felső harmada szemlélteti, ami arra is kíván utalni, hogy a vállalkozói ökoszisztémában és a közösségi finanszírozásplatformon megjelenő projektek csupán egy része képes elérni a régiós beágyazódás fázisát.

\section{Az empirikus kutatás}

A Pécsi Tudományegyetem 2015 decembere óta rendelkezik saját közösségi finanszírozási platformmal, mely kezdeményezés úttörőnek tekinthető a hazai felsőoktatás területén. A crowdfunding egyetemi vállalkozói ökoszisztémába történő ágyazása több szakaszban zajlott: első lépésként a Simonyi Üzlet- és Gazdaságfejlesztési Központ (Simonyi BEDC) 12 hetes Inkubációs Programja integrálta a közösségi finanszírozást a korai fázisú hallgatói ötletgenerálás, ötlet- és üzletfejlesztés folyamatába, ahol a program végére a hallgatóknak kampányt is kellett készíteniük, melynek indítását azonban a projekt jellege és érettségének foka határozta meg. A második szakaszban a nappali és levelező szakon alap- és mesterképzésen több vállalatfinanszírozással kapcsolatos kurzusba lett beépítve a közösségi finanszírozás mint oktatási tananyag, mely kitér a crowdfunding üzleti modelljeire, előnyeire és hátrányaira, kockázataira és hazai sikertörténeteire.

Az empirikus kutatásunk mintavétele 2015/2016-os tanév tavaszi félévében zajlott, 153 hallgatóra kiterjedő, nem reprezentatív kérdőíves lekérdezés formájában történt. A hallgatói mintavételnél ügyeltünk arra, hogy a crowdfundinggal kapcsolatos attitüd vizsgálatához jól elkülöníthető három csoportot alkossunk. A teljes minta $22 \%$-át olyan, legföképp levelezős hallgatók teszik ki, akik sosem hallottak még a közösségi finanszírozásról, még órai keretek között sem. 46\%-uk a tantervbe ágyazottan részesült crowdfunding oktatásban, előadás formájában hallott a témáról, 32\%-uk pedig részt vett a Simonyi BEDC valamelyik Inkubációs Programjában, ahol nem csak egy ötletfejlesztésen dolgoztak, hanem összekötöttük őket sikeres magyar crowdfunding kampányok szereplőivel is (4. ábra). 
4. ábra

A hallgatók mintán belüli eloszlása a crowdfunding oktatásának módja szerint

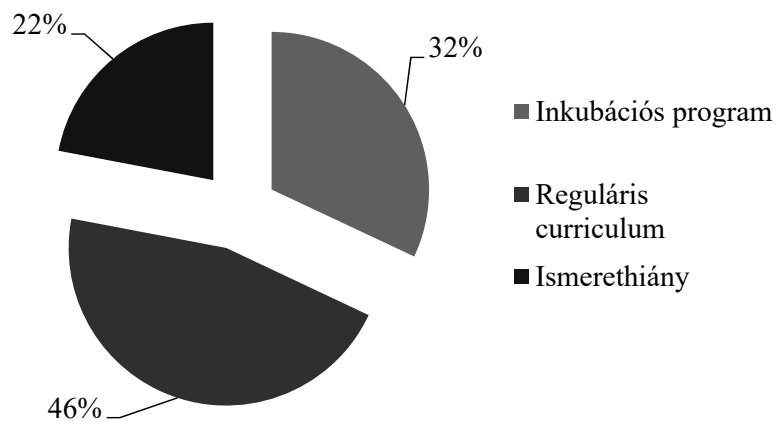

Forrás: saját szerkesztés

Rákérdeztünk minden hallgató esetén arra, hogy részt vennének-e egy crowdfunding kampány fejlesztésében? Arra is kerestük a választ, hogy annak oktatásmódja befolyásolja-e a hallgatói attitűdöt? Ami meglepő, hogy a crowdfunding iránti nyitottságban nincs különbség azon hallgatók között, akik ismerethiányosak a témában és azok között, akik óra keretében hallottak a jelenségröl, 58\%-uk szívesen venne részt ilyen kampányok fejlesztésében. Az Inkubációs Program hallgatóinál viszont magasabb ez az arány (5. ábra).

5. ábra

\section{A hallgatók hány százaléka lenne hajlandó részt venni crowdfunding kampányban?}

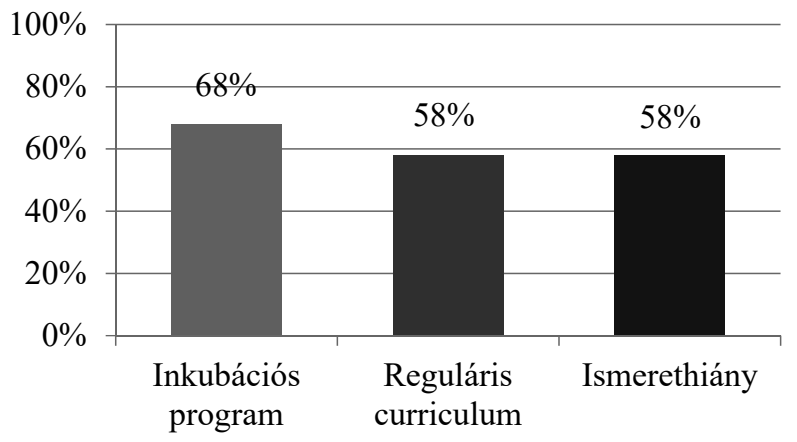

Forrás: saját szerkesztés

Kíváncsiak voltunk arra is, hogy lenne-e olyan ötletük, amire crowdfunding segítségével gyüjtenének forrást? Lényegi különbséget nem tapasztaltunk a három csoport között. A teljes minta 58\%-a jelezte azt, hogy ugyan nincs crowdfunding ötlete, de nyitott iránta és gondolkodik rajta.

Sokkal szembeötlőbb az eltérés abban a tekintetben, hogy van-e a hallgatókban belső indíttatás egy futó közösségi finanszírozási projekt pénzügyi támogatására? A vizsgálatunk során azt találtuk, hogy az ismerethiánnyal rendelkező hallgatók csupán egyharmada lenne hajlandó valamilyen összeggel segíteni crowdfunding kampányokat, a hagyományos tanterv keretei közé beépített crowdfunding oktatásban részesült hallgatók fele, míg az Inku- bációs Programban résztvevők kétharmada járulna hozzá szívesen egy ilyen kampány sikeréhez (6. ábra.).

6. ábra

A hallgatók hány százaléka lenne hajlandó támogatni crowdfunding kampányt?

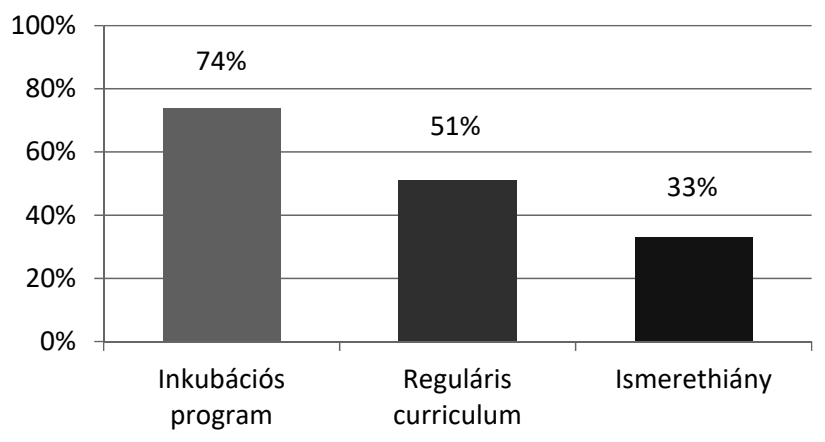

Forrás: saját szerkesztés

Teszteltük azt is, hogy milyen összegben támogatnák más hallgatói közösségi finanszírozási kampányokat? Legszívesebben 1.000 vagy 5.000 forinttal járulnának hozzá a kampányhoz, a teljes minta 6\%-a 10.000 forinttal is. Feltettük ugyanezt a kérdést már létező és müködő kis- és közepes méretü vállalkozások kampányainak támogatására vonatkozóan is. Azt találtuk, hogy nagyobb a bizalom az érettebb vállalkozások kampányai iránt és magasabb öszszegeket juttatnának a projekt sikeréért.

Jelenlegi közösségi finanszírozási platformunkat az angliai Hubbub szolgáltatja. Fizetési módok közül a PayPal és a Stripe adott, illetve van lehetőség még az offline gyüjtés készpénzletétként való rögzítésére is. Kérdőívezésünk során fontosnak tartottuk a PayPal ismertségének feltérképezését is. A hallgatók 93\%-a hallott a PayPal-ról, az utóbbiak 55\%-a már fizetett is vele. Az arányok jól mutatják a PayPal mérsékelt penetrációs mértékét a hallgatói gyakorlatban, egyben az egyetemi bázisú közösségi finanszírozási platform fizetéstechnikai korlátjait és lehetőségeit is jelzik. Jövőorientált alternatív fizetési módok kapcsán azt is megvizsgáltuk, hogy milyen mértékben használják a hallgatók saját mobiltelefonjukat fizetésre. A minta 86\%-a nem használja a mobilját fizetési céllal, ezért a PayPal mobilfizetéssel történő kiváltásának lehetőségét átmenetileg elvetettük, mint fejlesztési irányt.

A közösségi finanszírozási kampányok indítása után a siker egyik tényezője, a projektgazda körüli családtagok, ismerősök hálózata. A mintán belül a hallgatók 60\%-a gondolja úgy, hogy a környezetében lennének olyanok, akik nyitottak crowdfunding kampányok támogatására: a barátokat nagyobb mértékben érzik a téma iránt fogékonynak, mint a családtagokat.

\section{Következtetések}

Az egyetemek regionális társadalmi-gazdasági térben történő átalakuló szerepvállalása felértékeli az egyetemi bázisú vállalkozói kapacitásteremtés jelentőségét. Az egyetemen létrejövő innováció- és startupötletek piaci 
alapú finanszírozásának lehetőségei közül az egyetemi bázisú közösségi finanszírozást vizsgáltuk részleteiben. A hazai szakirodalomban hiánypótló empirikus kutatásunk alátámasztja, hogy az egyetemi vállalkozói ökoszisztémába integrált crowdfunding infrastruktúra hatékonyságát jól átgondolt tantervi és tanterven kívüli oktatási színterekkel is segíteni kell. Az oktatás módja - legyen az a tantárgyakban elhelyezett frontális elöadás vagy az Inkubációs Program vállalkozást ösztönző és interaktív, alkalmazott tanulási környezete - befolyásolja a közösségi finanszírozással kapcsolatos hallgatói attitüdöt. Az Inkubációs Program hallgatói magasabb részvételi szándékot és pénzügyi támogatási hajlandóságot mutattak, mint a kontrollcsoportok. Kutatásunk rávilágít arra, hogy az egyetemi vállalkozói ökoszisztémába ágyazott közösségi finanszírozás esetén önmagában nem elég az infrastruktúra-fejlesztés, azaz az internetes platform létrehozása, rendkívül fontosak még az ökoszisztéma-rendszerelemek közül a kultúrateremtés, az oktatási programokkal való támogatottság, a követendő hallgatói minták felmutatása és ezek szinergiáiból eredő összetett hatások.

A kutatás oktatás-módszertani tanulságainak levonása után indítottuk el az ún. oktatási célú crowdfunding (learning-based crowdfunding) folyamatot, melynek lényege, hogy a hallgatók különféle - informatikai, marketing és pénzügy - tantárgyak keretében saját crowdfunding ötleteik köré készítenek el kampányszöveget, opcionálisan videót, amit az egyetem crowdfunding platformjára fel is töltenek; ha komoly a szándék, akkor el is indítják a kampányt és a promóciót. Ezt megelőzően a kampányfejlesztéshez kooperatív tanulásszervezés megközelítéssel kapnak impulzusokat a tanóra alatt a crowdfunding sikertényezőiről, a támogatói típusokról, a kockázatokról, illetve a sikeres vállalkozói narratívákról. A tanórákon és egyéb hálózatokban felmerülő vállalkozói potenciállal rendelkező ötleteket az egyetemi ökoszisztémán belüli networkinggel és ötletfejlesztéssel támogatja a Simonyi BEDC.

\section{Felhasznált irodalom}

Acs, Z. J. - Armington, C. (2004): The Impact of Geographic Differences in Human Capital on Service Firm Formation Rates. Journal of Urban Economics, 56 (2), p. 244-278.

Alegre, I. - Moleskis, M. (2016): Crowdfunding: A Review and Research Agenda. IESE Business School, Working Paper WP-1142-E

Árváné Ványi Georgina - Katonáné Kovács Judit-Gál Tímea (2017): A vállalkozásfejlesztés oktatásának vizsgálata a magyar felsőoktatásban. Vezetéstudomány/Budapest Management Review, 48 (6-7), p. 49-56.

Autio, E. - Kenney, M. - Mustar, P. - Siegel, D. - Wright, $M$. (2014): Entrepreneurial Innovation: The Importance of Context. Research Policy, 43 (7), p. 1097-1108.

Baskerville, R. F. - Cordery, C. J. (2014): Crowdfunding: A Threat or Opportunity for University Research Funding? Available at SSRN: https://ssrn. com/abstract $=2458638$ or http://dx.doi.org/10.2139/ ssrn. 2458638

Baumol, W. J. (1993): Entrepreneurship, Management and the Structure of Payoffs. London: MIT Press

Bedö Zsolt (2015): Pécsi Tudományegyetem, Közgazdaságtudományi Kar, Simonyi Üzlet- és Gazdaságfejlesztési Központ, Stratégiai és Cselekvési terv

Brown, R. - Mason, C. (2014): Inside the High-tech Black Box: A Critique of Technology Entrepreneurship Policy. Technovation, 34 (12), p. 773-784.

Clark, B. R. (1998): Creating Entrepreneurial Universities: Organizational Pathways of Transformation". Oxford: Pergamon, IAU Press

Döry Tibor - Gajzágó Éva (2015): Vállalkozások és innovációs közremüködő szervezetek együttmüködései Közép-Dunántúlon. Vezetéstudomány, 46 (2), p. 47.56.

Etzkowitz, H. - Leydesdorff, L. (2000): The Dynamics of Innovation: from National Systems and "Mode 2" to a Triple Helix of University-Industry-Government Relations. Research Policy, 29 (2), p. 109-123.

Etzkowitz, H. (1998): The Norms of Entrepreneurial Science: Cognitive Effects of the New University-Industry Linkages. Research Policy, 27 (8), p. 823-833.

Feld, B. (2012): Startup Communities: Building an Entrepreneurial Ecosystem in Your City. New York: Wiley

Feldman, M. P. (2001). The Entrepreneurial Event Revisited: Firm Formation in a Regional Context. Industrial and Corporate Change, 10 (4), p. 861-891.

Florida, R. - Adler, P. - Mellander, C. (2016): The City as Innovation Machine. Working Paper. Toronto: Martin Prosperity Institute, Rotman School of Management, University of Toronto

Gál Tímea - Katonáné Kovács Judit - Arváné Ványi Georgina (2017): Egy innovatív, finn vállalkozói képzés módszertani eszközeinek elemző értékelése és európai térnyerésének bemutatása. Vezetéstudomány/ Budapest Management Review, 48 (8-9), p. 78-88.

Glaeser, E. L. - Rosenthal, S. S. - Strange, W. C. (2010): Urban Economics and Entrepreneurship. Journal of Urban Economics, 67 (1), p. 1-14.

Goldstein, H. A. (2009): What we Know and What we Don't Know about the Regional Economic Impacts of Universities". In: Varga, A. (ed.): Universities, Knowledge Transfer and Regional Development: Geography, Entrepreneurship and Policy. Cheltenham, UK: Northampton, MA, USA: Edward Elgar, p. 11-35.

Göktepe-Hulten, D. - Mahagaonkar, P. (2010): Inventing and Patenting Activities of Scientists: in the Expectation of Money or Reputation? Journal of Technology Transfer, 35 (4), p. 401-423.

Henrekson, M. - Sanandaji, T. (2014): Small Business Activity Does not Measure Entrepreneurship. Proceedings of the National Academy of Sciences, 111 (5), p. 1760-1765.

Imreh-Tóth Mónika (2015): Vállalkozásoktatási jó gyakorlatok adaptációs lehetőségei a hazai felsőoktatásban - a Szegedi Tudományegyetem példája. Vezetéstudomány, 46 (2), p. 57-67. 
Isenberg, D. J. (2011): Introducing the Entrepreneurship Ecosystem: Four Defining Characteristics. Forbes, http://www.forbes.com/sites/danisenberg/2011/05/25/ introducing-the-entrepreneurshipecosystem-four-defining-characteristics/

Kantis, H. - Frederico, J. (2011): Entrepreneurial Ecosystems in Latin America: the role of policies. Download from: http:/www.innovacion. gob.cl/wp-content/ uploads/2012/06/Entrepreneurial-Ecosystems-in-Latin-America_the-role-of-policies.pdf

Luger, M. I. - Goldstein, H. A. (1997): What is the Role of Public Universities in Regional Economic Development? In: Bingham, R. D. - Mier, R. (eds.): Dilemmas of Urban Economic Development: Issues in Theory and Practice. Urban Affairs Annual Reviews 47. Thousand Oaks, California: Sage Publications, p. 104-134.

Malecki, E. J. (2011): Connecting Local Entrepreneurial Ecosystems to Global Innovation Networks: Open Innovation, Double Networks and Knowledge Integration. International Journal of Entrepreneurship and Innovation Management, (14), p. 36-59.

Muller, M. - Geyer, W. - Soule, T. - Daniels, S. - Cheng, L. (2013): Crowdfunding Inside the Enterprise: Employee-initiatives for Innovation and Collaboration. Proceedings of the SIGCHI Conference on Human Factors in Computing Systems, p. 503-512.

Muller, M. - Geyer, W. - Soule, T. - Wafer, J. (2014): Geographical and Organizational Distances in Enterprise Crowdfunding. Proceedings of the 17th ACM Conference on Computer supported cooperative work \& social computing, p. 778-789.

Napier, G. - Hansen, C. (2011): Ecosystems for Young Scaleable Firms. FORA Group

Stam, E. - Hartog, C. - Van Stel, A. - Thurik, R. (2011): Ambitious Entrepreneurship and MacroEconomic growth. In: Minniti, M. (ed.): The Dynamics of Entrepreneurship. Evidence from the Global Entrepreneurship Monitor Data. Oxford: Oxford University Press

Stam, E. - Bosma, N. - Van Witteloostuijn, A - de Jong, J. - Bogaert, S. - Edwards, N. - Jaspers, F. (2012): Am- bitious Entrepreneurship. A Review of the Academic Literature and New Directions for Public Policy. Den Haag: Adviesraad voor Wetenschap en Technologie-beleid (AWT)

Stam, E. - Suddle, K. - Hessels, J. - Van Stel, A. (2009): High-Growth Entrepreneurs, Public Policies and Economic Growth. In: Leitao, J. - Baptista, R. (eds.): Public Policies for Fostering Entrepreneurship: A European Perspective. New York: Springer, p. $91-110$.

Stam, E. (2015): Entrepreneurial Ecosystems and Regional Policy: A Sympathetic Critique. European Planning Studies, 23 (9), p. 1759-1769.

Szerb László (2017): A vállalkozói ökoszisztéma Magyarországon a 2010-es években - helyzetértékelés és szakpolitikai javaslatok. Vezetéstudomány/Budapest Management Review, 48 (6-7), p. 2-14.

Ucbasaran, D. - Westhead, P. - Wright, M. (2001): The Focus of Entrepreneurial Research: Contextual and Process Issues. Entrepreneurship Theory and Practice, 25(4), p. 57-80.

Welter, F. (2011): Contextualizing Entrepreneurship Conceptual Challenges and Ways Forward. Entrepreneurship Theory and Practice, 35, p. 165-184.

Wieck, E. - Bretschneider, U. - Leimeister, J. M. (2013): Funding from the Crowd: An Internet-Based Crowdfunding Platform to Support Business Set-Ups from Universities. International Journal of Cooperative Information Systems, Vol. 22, No. 3 Available at SSRN: https://ssrn.com/abstract $=2475414$

Wong, P. - Ho, Y. - Autio, E. (2005): Entrepreneurship, Innovation and Economic Growth: Evidence from GEM data. Small Business Economics, 24(3), p. 335-350.

Zacharakis, A. - Shepard, D. - Coombs, J. (2003): The Development of Venture-Capital-Backed Internet Companies: an Ecosystem Perspective. Journal of Business Venturing, (18), p. 217-231.

Zahra, S. A. - Wright, M., - Abdelgawad, S. G. (2014): Contextualization and the Advancement of Entrepreneurship Research. International Small Business Journal, (32), p. 479-500. 